\title{
Converted neural cells: induced to a cure?
}

\author{
Weiqi Zhang ${ }^{1 *}$, Shunlei Duan ${ }^{1 *}$, Ying Li $^{1}$, Xiuling Xu ${ }^{1}$, Jing $Q u^{1 \bowtie}$, Weizhou Zhang ${ }^{2}$, Guang-Hui Liu ${ }^{1 凶}$ \\ ${ }^{1}$ National Laboratory of Biomacromolecules, Institute of Biophysics, Chinese Academy of Sciences, Beijing 100101, China \\ ${ }^{2}$ Laboratory of Gene Regulation and Signal Transduction, Department of Pharmacology, School of Medicine, University of \\ California, San Diego, La Jolla, CA 92093, USA \\ $\triangle$ Correspondence: ghliu@ibp.ac.cn (G.-H. Liu), w4zhang@ucsd.edu (W. Zhang), jqu@salk.edu (J. Qu) \\ Received February 10, 2012 Accepted February 13, 2012
}

\begin{abstract}
Many neurodegenerative disorders such as Parkinson's disease (PD), amyotrophic lateral sclerosis (ALS) and others often occur as a result of progressive loss of structure or function of neurons. Recently, many groups were able to generate neural cells, either differentiated from induced pluripotent stem cells (iPSCs) or converted from somatic cells. Advances in converted neural cells have opened a new era to ease applications for modeling diseases and screening drugs. In addition, the converted neural cells also hold the promise for cell replacement therapy (Kikuchi et al., 2011; Krencik et al., 2011; Kriks et al., 2011; Nori et al., 2011; Rhee et al., 2011; Schwartz et al., 2012). Here we will mainly discuss most recent progress on using converted functional neural cells to treat neurological diseases and highlight potential clinical challenges and future perspectives.
\end{abstract}

KEYWORDS converted neural cell, pluripotent stem cell, transdifferentiation, transplantation, neurodegenerative diseases

\section{INTRODUCTION}

Neurological disorders that develop due to degeneration or loss of neural cells, such as Parkinson's disease (PD), Alzheimer's disease (AD), amyotrophic lateral sclerosis (ALS), and stroke can be devastating and sometimes life-threatening (Ross and Poirier, 2004; llieva et al., 2009). Disease models based on converted neural cells ( $\mathrm{cN}$, refer collectively to the neural cells differentiated from pluripotent stem cells (PSCs) or converted from somatic cells) have been proved effective to investigate mechanisms of certain neurodevelopmental problems and neurodegenerative diseases, identify candidate pathogenic genes, and screen potential drugs (Marchetto et al., 2010; Brennand et al., 2011; Devine et al., 2011; Dolmetsch and Geschwind, 2011; Grskovic et al., 2011; Han et al., 2011; Kim et al., 2011c; Koch et al., 2011; Nguyen et al., 2011; Pasca et al., 2011; Qiang et al., 2011; Yagi et al., 2011; Israel et al., 2012). For therapeutic purposes, one of the strategies to treat neurodegenerative disease is to replace degenerative neurons with newly produced ones during the course of disease progression. Prior to advances recently made in $\mathrm{cN}$, various cell types including embryonic stem cells (ESCs), mesenchymal stem cells (MSCs), and fetal neural stem cells (NSCs) have been proposed as donor cells of the cell replacement therapy to treat these diseases. However, there are major obstacles including ethical controversy, immune rejection, and limited cell source that severely impede their potential clinical applications. Until recently, induced pluripotent stem cells (iPSCs) technology offers an unprecedented opportunity to generate patient-specific neural stem/progenitor cells (NSCs/NPCs) in vitro for transplantation purpose. The converted NSCs/NPCs provide unlimited source of donor cells if can be used for cell replacement therapy, at the same time bypassing both immune rejection issue and ethical concern of employing embryonic tissues (Seifinejad et al., 2010; Barrilleaux and Knoepfler, 2011). The promise of using iPSC-derived NPCs for therapy was strongly supported by the evidence from animal models whose pathological phenotypes can be successfully rescued by effective delivery and integration of converted NPCs into the animal brains (Kikuchi et al., 2011; Kriks et al., 2011; Rhee et al., 2011). More recently, induced neural cells (iNs) derived by direct lineage conversion (also termed as transdifferentiation) provide an alternative way to model neurodegenerative diseases and serve as potential donor cells for autologous replacement therapy (Vierbuchen et al., 2010; Kim et al., 2011b; Qiang et al., 2011; Lujan et al., 2012).

\footnotetext{
*These authors contributed equally to the work.
} 
Below we will focus on in vivo properties of $\mathrm{cNs}$, and discuss their therapeutic potentials to treat neurological disorders.

\section{CN AND PD}

$\mathrm{PD}$ is one of the most prevalent neurodegenerative disorders and characterized by impaired dopaminergic neurons in substantia nigra (Berke and Hyman, 2000; Huse et al., 2005). In principle, replacement of lost dopaminergic neurons could ameliorate PD symptoms. This was proved to be true by clinical trials where some PD patients grafted with dopaminergic neuroblasts isolated from human fetal mesencephalic tissue recover, at least partially, from disease symptoms (Lindvall and Björklund, 2011). The major obstacle lies in the difficulty to obtain human fetal tissue. To improve cell therapy approach used in clinic, PSCs including ESCs and iPSCs could serve as excellent cellular sources to produce dopaminergic neurons (Pawitan, 2011). hESC-derived midbrain dopamine neurons have been successfully transplanted into PD patients' brains and some favorable results were achieved in cell replacement trials (Bjorklund et al., 2002; Kim et al., 2002; Wernig et al., 2004; Roy et al., 2006; Sanchez-Pernaute et al., 2008; Yang et al., 2008; Kriks et al., 2011). Studer and colleagues described the differentiation of hESCs into functional dopaminergic neurons, which could be integrated into receiver tissue to ameliorate PD symptoms in mice, rats and monkeys without forming tumors (Kriks et al., 2011). The milestone improvement in this new strategy is that hPSCs were stepwise differentiated into substantia nigra neurons through floor plate cell stage. The generated neural cells exhibited similar gene expression profile, electrophysiological properties and the ability to release dopamine as nigral neurons, and survived well after transplantation procedures (Kriks et al., 2011). However, transplantation with hESC derivatives critically suffers from ethical controversy and practical limitation. In contrast, dopaminergic neurons derived from patient specific iPSCs are ideal cellular sources for personalized replacement therapy. The technique to produce dopaminergic neurons from iPSCs was already established (Deleidi et al., 2011). Fibroblasts from sporadic PD patients could be reprogrammed and differentiated into dopaminergic neurons similarly as those from healthy individuals (Park et al., 2008; Wernig et al., 2008; Soldner et al., 2009). Rhee and colleagues were able to generate dopaminergic neurons from protein factors-based iPSCs (Rhee et al., 2011). The dopaminergic neurons could be successfully transplanted into brains of disease-bearing rats, which significantly rescued the motor deficits caused by 6-OHDAlesion. Integration and survival of iPSCs-derived midbrain dopaminergic neurons were also observed in the brain of a monkey PD model (Kikuchi et al., 2011). Therefore, all these results shed light on using iPSCs-derived neural cells for therapeutic materials to treat PD.
iNs directly converted from somatic cells recently joined the family for the promise of cell replacement therapy. Four independent groups reported the generation of dopamine (DA) neurons by direct lineage conversion (Caiazzo et al., 2011; Kim et al., 2011a, 2011b; Pfisterer et al., 2011; Liu et al., 2012b). Liu's group robustly converted human fibroblasts to DA neuron-like cells using five factors together including Mash1, Ngn2, Sox2, Nurr1, and Pitx3 (Liu et al., 2012b). These cells expressed markers of DA neurons, exhibited DA uptake and production as well as DA neuron-specific electrophysiological profiles. When transplanted into the middle of the striatum of 6-OHDA-lesioned rats, the rats exhibited a significant stabilization of their rotational behaviors. Kim and colleagues also ectopically expressed certain defined factors in mouse tail tip fibroblasts to induce Pitx $3^{+}$neurons that closely resemble mouse DA neurons. When these induced DA (iDA) neurons were transplanted into the striatum of mice with 6-OHDA lesion, the moving behavior of these mice was significantly improved (Kim et al., 2011b). Thus, iDA neurons produced from somatic fibroblasts by direct lineage reprogramming hold great promise for cell-based therapy.

\section{CN AND ALS}

ALS is a fatal and progressive neurodegenerative disease characterized by gradual loss of motor neurons in the brainstem and spinal cord, leading to loss of muscle control and eventual paralysis (Cleveland and Rothstein, 2001; Boillee et al., 2006). ALS patients may benefit from combinatory therapies involving cell replacement approaches. ALS-bearing animals have been transplanted with donor cells from different origins including MSCs and NPCs to examine their potential therapeutic effects. These approaches were relatively effective in treating disease-bearing animals as life span and motor neuron survival in the hosts were significantly prolonged (Dimos et al., 2008). However, when come to patients, safety and efficacy issues become apparent. Recently iPSCs-derived motor neurons brought new hope for ALS treatment. In 2008, Dimos et al. reported that iPSCs from an ALS patient could be differentiated into motor neurons (Dimos et al., 2008). In 2009, Ebert et al. and Karumbayaram et al. suggested the potential use of iPSCs-derived motor neurons for the treatment of motor neuron diseases (Ebert et al., 2009; Karumbayaram et al., 2009). More recently, Son et al. directly converted mouse and human fibroblasts to induced motor neurons (iMNs) by defined factors. These iMNs exhibited engraftment capacity and could be differentiated into functional neural subtypes in vivo (Son et al., 2011). Whether or not these converted motor neurons can be successfully transplanted to treat ALS awaits further validation.

\section{CN AND STROKE}

Stroke is one of the most common causes of death in human 
being and there is no effective treatment available to restore lost neurological function of patients after stroke (Donnan et al., 2008). In the past years, numerous studies have shown that stem cell-based transplantation is an important therapeutic approach for stroke. In 2010, Chen et al. reported that when rats were directly injected with iPSCs into the damaged area of cortex, the infarct size was significantly decreased and their moving behavior was largely improved in rotarod and grasping tasks (Chen et al., 2010). However, Kawai et al. did not find any beneficial effect after iPSC transplantation in mice (Kawai et al., 2010). The discrepancy could be explained by different differentiation and transplantation protocols employed, or different capabilities between species of receiving exogenous iPSCs and functionally incorporating them into nervous system. Recently, Jensen et al. transplanted NSCs derived from human iPSCs into a stroke model, which rescued the stroke volume and behavioral function (Jensen et al., 2011). Thus the generation of iPSCs from human somatic cells may still offer promising cellular sources for cell-based therapy (Fujioka et al., 2010).

\section{CN AND OTHER NEUROLOGICAL DISEASES}

$\mathrm{cN}$ has also shown great potential to treat various neurological diseases like AD (Qiang et al., 2011), spinal cord injury (SCl) (Nori et al., 2011), and other neurodegenerative diseases that are summarized in Table 1. One of the most important breakthroughs comes from Lanza group who successfully transplanted $\mathrm{hESC}$-derived retinal pigment epithelium cells into the eyes of patients with macular degeneration, which led to improved visual activities (Schwartz et al., 2012).

\section{CONCLUSION AND FUTURE PROSPECTS}

cNs provide an unprecedented opportunity to serve as patient-specific autologous transplantation materials for cell replacement therapy of neuronal lesions and incurable neurodegenerative diseases. Animal studies and clinical trials indicate that $\mathrm{cN}$-based cell therapy is very promising to treat neurological diseases. Challenges remain before these cell materials can be safely introduced into human patients.

Table 1 cN-based cell replacement therapy in preclinical animal models of neurological diseases

\begin{tabular}{|c|c|c|c|c|c|}
\hline Disease & Species & Model type & Transplanted cells & Outcome & Reference \\
\hline \multirow{8}{*}{ PD } & Rat & 6-OHDA & $\begin{array}{l}\text { DA NPCs derived } \\
\text { from iPSCs }\end{array}$ & $\begin{array}{l}\text { Long-term survival } \\
\text { Differentiation to DA }\end{array}$ & Cai et al., 2010 \\
\hline & Rat & 6-OHDA & $\begin{array}{l}\text { PD patient iPSC-derived } \\
\text { DA neurons }\end{array}$ & $\begin{array}{l}\text { Functional neurons with tumor-like cells at } \\
\text { the site of graft }\end{array}$ & Hargus et al., 2010 \\
\hline & Rat & $6-\mathrm{OHDA}$ & $\begin{array}{l}\text { iPSC-derived DA } \\
\text { neurons }\end{array}$ & Improved motor behavior & Wernig et al., 2008 \\
\hline & Rat & 6-OHDA & $\begin{array}{l}\text { iPSC-derived DA } \\
\text { neurons }\end{array}$ & Improved motor behavior & Swistowski et al., 2010 \\
\hline & Rat & $6-\mathrm{OHDA}$ & $\begin{array}{l}\text { Directly converted DA neuron- } \\
\text { like cells }\end{array}$ & Improved rotational behaviors & Liu et al., 2012b \\
\hline & Rat & $6-\mathrm{OHDA}$ & $\begin{array}{l}\text { Directly converted DA neuron- } \\
\text { like Pitx }{ }^{+} \text {neuronal cells }\end{array}$ & $\begin{array}{l}\text { Improved performance in amphetamine- } \\
\text { induced rotation assay }\end{array}$ & Kim et al., $2011 \mathrm{~b}$ \\
\hline & Mouse & NOD-SCID & Human iPSC-derived NPCs & Survival of midbrain dopaminergic neurons & Kikuchi et al., 2011 \\
\hline & Monkey & MPTP & Human iPSC-derived NPCs & Survival of midbrain dopaminergic neurons & Kikuchi et al., 2011 \\
\hline \multirow{4}{*}{ Stroke } & Rat & MCAO & $\mathrm{iPSCs}+\mathrm{FG}$ & Improved motor behavior & Chen et al., 2010 \\
\hline & Mouse & MCAO & Mouse iPSCs & $\begin{array}{l}\text { Decreased infarct size, } \\
\text { improved motor } \\
\text { Performance, } \\
\text { decreased inflammatory } \\
\text { cytokines }\end{array}$ & Kawai et al., 2010 \\
\hline & Mouse & MCAO & Mouse iPSCs & Tridermal tumorigenesis & Yamashita et al., 2011 \\
\hline & Rat & MCAO & iPSCs & $\begin{array}{l}\text { Reduction of stroke volume and } \\
\text { behavioral recovery }\end{array}$ & Jensen et al., 2011 \\
\hline \multirow{3}{*}{$\mathrm{SCl}$} & Mouse & $\begin{array}{l}\text { Contusion } \\
\text { model }\end{array}$ & $\begin{array}{l}\text { iPSC-derived } \\
\text { neurospheres }\end{array}$ & $\begin{array}{l}\text { Remyelination and } \\
\text { functional recovery }\end{array}$ & Tsuji et al., 2010 \\
\hline & Rat & $\begin{array}{l}\text { Contusion } \\
\text { model }\end{array}$ & iPSC-derived astrocytes & Enhanced sensitivity to mechanical stimulus & Hayashi et al., 2011 \\
\hline & Mouse & NOD-SCID & $\begin{array}{l}\text { iPSC-derived } \\
\text { neurospheres }\end{array}$ & $\begin{array}{l}\text { Enhanced Angiogenesis and Axonal } \\
\text { regrowth }\end{array}$ & Nori et al., 2011 \\
\hline
\end{tabular}

6-OHDA, 6-hydroxydopamine; DA, dopaminergic; FG, fibrin glue; iPSC, induced-pluripotent stem cell; MMP9, matrix metalloproteinase-9; MCAO, middle cerebral artery occlusion; PD, Parkinson's disease; pVEGFR2, phosphorylated vascular endothelial growth factor receptor 2; NPC, neural progenitor cell; SCl, spinal cord injury; NOD-SCID, nonobese diabetic (NOD)-severe combined immunodeficient(SCID); MPTP, 1-methyl-4phenyl-1,2,3,6-tetrahydropyridine. 
iPSC-derived neural cells bear the risk of teratoma formation, immaturity of differentiated cells and inability to integrate into receiver tissue. Although these risks can be minimized by improving directed differentiation protocols to generate functionally normal cNs and finding a way to completely eliminate residual pluripotent cells before transplantation (Kriks et al., 2011), the fundamental issue that should be further addressed is whether cNs derived from iPSCs are safe after long-term in vivo integration. Notably, genetic aberrancy introduced into iPSCs during reprogramming will be retained in terminally differentiated neural cells. It is uncertain if these changes will affect cellular functions in patients who receive these cells. To avoid unexpected drawbacks due to genetic abnormalities, genomic intact $\mathrm{cNs}$ induced by small molecules or other chemically defined conditions should be preferable for clinical applications (Davis et al., 2011; Rhee et al., 2011). Compared to cNs derived from iPSCs, the ones directly converted from somatic cells have reduced risk of teratoma and cancer formation due to their postmitotic state. Nevertheless, these cells exhibit very limited proliferative ability and may not provide enough autologous donor cells for transplantation. In this case, conversion of fibroblasts into expandable NSCs may be an ideal strategy (Kim et al., 2011a; Lee et al., 2011). It is worth to note that long-term propagation of NSCs in vitro could cause genomic instability (Varela et al., 2012). Another concern of cNs obtained from direct lineage conversion is how to correct pathogenic mutations that cause family neurodegenerative diseases. So far, while various gene editing tools have been successfully used for genetic corrections in patient specific iPSCs (Hockemeyer and Jaenisch, 2010; Kim and Svendsen, 2011; Liu et al., 2011; Pan et al., 2011; Liu et al., 2012a; Zhang et al., 2012), development of more powerful gene editing tools remains a challenge to manipulate genome of somatic cells and represents a critical step for cNs-based therapy.

In summary, recent advances on the successful use of cNs in transplantations are exciting and open a new avenue to treat various neurodegenerative diseases. Experiments on animals of disease models have already demonstrated that cNs-based cell replacement therapies are effective in curing certain neurodegenerative diseases. The translation from animals to patients awaits further trials. Major breakthroughs, like powerful gene-editing tools for somatic cells and new techniques to achieve enough, safe, and functional donor cells, have to be made to reduce any potential risk from engrafted autologous tissues. At the same time to take cautions when come to patients, cNs-based cell therapy represents a new era of regenerative medicine to solve incurable medical problems and may finally lead to the cure of some neurodegenerative disorders in the near future.

\section{ACKNOWLEDGEMENTS}

Work in the laboratory of GHL was supported by 100 Talents Pro- gram of the Chinese Academy of Sciences.

\section{ABBREVIATIONS}

$A D$, Alzheimer's disease; ALS, amyotrophic lateral sclerosis; DA, dopamine; ESCs, embryonic stem cells; iMNs, induced motor neurons; iNs, induced neural cells; MSCs, mesenchymal stem cells; NSCs, fetal neural stem cells; PD, Parkinson's disease; SCl, spinal cord injury

\section{REFERENCES}

Barrilleaux, B., and Knoepfler, P.S. (2011). Inducing iPSCs to escape the dish. Cell Stem Cell 9, 103-111.

Berke, J.D., and Hyman, S.E. (2000). Addiction, dopamine, and the molecular mechanisms of memory. Neuron 25, 515-532.

Bjorklund, L.M., Sanchez-Pernaute, R., Chung, S., Andersson, T., Chen, I.Y., McNaught, K.S., Brownell, A.L., Jenkins, B.G., Wahlestedt, C., Kim, K.S., et al. (2002). Embryonic stem cells develop into functional dopaminergic neurons after transplantation in a Parkinson rat model. Proc Natl Acad Sci USA 99, 2344-2349.

Boillee, S., Vande Velde, C., and Cleveland, D.W. (2006). ALS: a disease of motor neurons and their nonneuronal neighbors. Neuron 52, 39-59.

Brennand, K.J., Simone, A., Jou, J., Gelboin-Burkhart, C., Tran, N., Sangar, S., Li, Y., Mu, Y., Chen, G., Yu, D., et al. (2011). Modelling schizophrenia using human induced pluripotent stem cells. Nature 473, 221-225.

Cai, J., Yang, M., Poremsky, E., Kidd, S., Schneider, J.S., and lacovitti, L. (2010). Dopaminergic neurons derived from human induced pluripotent stem cells survive and integrate into 6-OHDA-lesioned rats. Stem Cells Dev 19, 1017-1023.

Caiazzo, M., Dell'Anno, M.T., Dvoretskova, E., Lazarevic, D., Taverna, S., Leo, D., Sotnikova, T.D., Menegon, A., Roncaglia, P., Colciago, G., et al. (2011). Direct generation of functional dopaminergic neurons from mouse and human fibroblasts. Nature 476 , 224-227.

Chen, S.J., Chang, C.M., Tsai, S.K., Chang, Y.L., Chou, S.J., Huang, S.S., Tai, L.K., Chen, Y.C., Ku, H.H., Li, H.Y., et al. (2010). Functional improvement of focal cerebral ischemia injury by subdural transplantation of induced pluripotent stem cells with fibrin glue. Stem Cells Dev 19, 1757-1767.

Cleveland, D.W., and Rothstein, J.D. (2001). From Charcot to Lou Gehrig: deciphering selective motor neuron death in ALS. Nat Rev Neurosci 2, 806-819.

Davis, H., Guo, X., Lambert, S., Stancescu, M., and Hickman, J.J. (2011). Small molecule induction of human umbilical stem cells into myelin basic protein positive oligodendrocytes in a defined three-dimensional environment. ACS Chemical Neuroscience 3, 31-39.

Deleidi, M., Hargus, G., Hallett, P., Osborn, T., and Isacson, O. (2011). Development of histocompatible primate-induced pluripotent stem cells for neural transplantation. Stem Cells 29, 1052-1063. 
Devine, M.J., Ryten, M., Vodicka, P., Thomson, A.J., Burdon, T., Houlden, H., Cavaleri, F., Nagano, M., Drummond, N.J., Taanman, J.W., et al. (2011). Parkinson's disease induced pluripotent stem cells with triplication of the alpha-synuclein locus. Nat Commun 2, 440.

Dimos, J.T., Rodolfa, K.T., Niakan, K.K., Weisenthal, L.M., Mitsumoto, H., Chung, W., Croft, G.F., Saphier, G., Leibel, R., Goland, R., et al. (2008). Induced pluripotent stem cells generated from patients with ALS can be differentiated into motor neurons. Science 321 , 1218-1221.

Dolmetsch, R., and Geschwind, D.H. (2011). The human brain in a dish: the promise of iPSC-derived neurons. Cell 145, 831-834.

Donnan, G.A., Fisher, M., Macleod, M., and Davis, S.M. (2008). Stroke. Lancet 371, 1612-1623.

Ebert, A.D., Yu, J., Rose, F.F. Jr, Mattis, V.B., Lorson, C.L., Thomson, J.A., and Svendsen, C.N. (2009). Induced pluripotent stem cells from a spinal muscular atrophy patient. Nature 457, 277-280.

Fujioka, T., Shimizu, N., Yoshino, K., Miyoshi, H., and Nakamura, Y. (2010). Establishment of induced pluripotent stem cells from human neonatal tissues. Human cell. Off J Human Cell Res Soc 23, 113-118.

Grskovic, M., Javaherian, A., Strulovici, B., and Daley, G.Q. (2011). Induced pluripotent stem cells--opportunities for disease modelling and drug discovery. Nat Rev Drug Discov 10, 915-929.

Han, S.S., Williams, L.A., and Eggan, K.C. (2011). Constructing and deconstructing stem cell models of neurological disease. Neuron 70, 626-644.

Hargus, G., Cooper, O., Deleidi, M., Levy, A., Lee, K., Marlow, E., Yow, A., Soldner, F., Hockemeyer, D., Hallett, P.J., et al. (2010). Differentiated Parkinson patient-derived induced pluripotent stem cells grow in the adult rodent brain and reduce motor asymmetry in Parkinsonian rats. Proc Natl Acad Sci USA 107, 15921-15926.

Hayashi, K., Hashimoto, M., Koda, M., Naito, A.T., Murata, A., Okawa, A., Takahashi, K., and Yamazaki, M. (2011). Increase of sensitivity to mechanical stimulus after transplantation of murine induced pluripotent stem cell-derived astrocytes in a rat spinal cord injury model. J Neurosurg Spine 15, 582-593.

Hockemeyer, D., and Jaenisch, R. (2010). Gene targeting in human pluripotent cells. Cold Spring Harb Symp Quant Biol 75, 201-209.

Huse, D.M., Schulman, K., Orsini, L., Castelli-Haley, J., Kennedy, S., and Lenhart, G. (2005). Burden of illness in Parkinson's disease. Movement disorders. Off J Move Dis Soc 20, 1449-1454.

llieva, H., Polymenidou, M., and Cleveland, D.W. (2009). Non-cell autonomous toxicity in neurodegenerative disorders: ALS and beyond. J Cell Biol 187, 761-772.

Israel, M.A., Yuan, S.H., Bardy, C., Reyna, S.M., Mu, Y., Herrera, C., Hefferan, M.P., Van Gorp, S., Nazor, K.L., Boscolo, F.S., et al. (2012). Probing sporadic and familial Alzheimer's disease using induced pluripotent stem cells. Nature 482, 216-220.

Jensen, M.B., Yan, H., Krishnaney-Davison, R., Al Sawaf, A., and Zhang, S.C. (2011). Survival and differentiation of transplanted neural stem cells derived from human induced pluripotent stem cells in a rat stroke model. J Stroke Cerebrovasc Dis: the official journal of National Stroke Association.
Karumbayaram, S., Novitch, B.G., Patterson, M., Umbach, J.A., Richter, L., Lindgren, A., Conway, A.E., Clark, A.T., Goldman, S.A., Plath, K., et al. (2009). Directed differentiation of human-induced pluripotent stem cells generates active motor neurons. Stem Cells 27, 806-811.

Kawai, H., Yamashita, T., Ohta, Y., Deguchi, K., Nagotani, S., Zhang, X., Ikeda, Y., Matsuura, T., and Abe, K. (2010). Tridermal tumorigenesis of induced pluripotent stem cells transplanted in ischemic brain. J Cerebral Blood Flow Met: official journal of the International Society of Cerebral Blood Flow and Metabolism 30, 1487-1493.

Kikuchi, T., Morizane, A., Doi, D., Onoe, H., Hayashi, T., Kawasaki, T., Saiki, H., Miyamoto, S., and Takahashi, J. (2011). Survival of human induced pluripotent stem cell-derived midbrain dopaminergic neurons in the brain of a primate model of Parkinson's disease. J Parkinson's Dis, 395-412.

Kim, H.W., and Svendsen, C.N. (2011). Gene editing in stem cells hits the target. Cell Stem Cell 9, 93-94.

Kim, J., Efe, J.A., Zhu, S., Talantova, M., Yuan, X., Wang, S., Lipton, S.A., Zhang, K., and Ding, S. (2011a). Direct reprogramming of mouse fibroblasts to neural progenitors. Proc Natl Acad Sci USA 108, 7838-7843.

Kim, J., Su, S.C., Wang, H., Cheng, A.W., Cassady, J.P., Lodato, M.A., Lengner, C.J., Chung, C.Y., Dawlaty, M.M., Tsai, L.H., et al. (2011b). Functional integration of dopaminergic neurons directly converted from mouse fibroblasts. Cell Stem Cell 9, 413-419.

Kim, J.H., Auerbach, J.M., Rodriguez-Gomez, J.A., Velasco, I., Gavin, D., Lumelsky, N., Lee, S.H., Nguyen, J., Sanchez-Pernaute, R., Bankiewicz, K., et al. (2002). Dopamine neurons derived from embryonic stem cells function in an animal model of Parkinson's disease. Nature 418, 50-56.

Kim, K.Y., Hysolli, E., and Park, I.H. (2011c). Neuronal maturation defect in induced pluripotent stem cells from patients with Rett syndrome. Proc Natl Acad Sci USA 108, 14169-14174.

Koch, P., Breuer, P., Peitz, M., Jungverdorben, J., Kesavan, J., Poppe, D., Doerr, J., Ladewig, J., Mertens, J., Tuting, T., et al. (2011). Excitation-induced ataxin-3 aggregation in neurons from patients with Machado-Joseph disease. Nature 480, 543-546.

Krencik, R., Weick, J.P., Liu, Y., Zhang, Z.J., and Zhang, S.C. (2011). Specification of transplantable astroglial subtypes from human pluripotent stem cells. Nat Biotechnol 29, 528-534.

Kriks, S., Shim, J.W., Piao, J., Ganat, Y.M., Wakeman, D.R., Xie, Z., Carrillo-Reid, L., Auyeung, G., Antonacci, C., Buch, A., et al. (2011). Dopamine neurons derived from human ES cells efficiently engraft in animal models of Parkinson's disease. Nature 480, 547-551.

Lee, S.T., Chu, K., Jung, K.H., Song, Y.M., Jeon, D., Kim, S.U., Kim, M., Lee, S.K., and Roh, J.K. (2011). Direct generation of neurosphere-like cells from human dermal fibroblasts. PLoS ONE 6, e21801.

Lindvall, O., and Björklund, A. (2011). Cell therapeutics in Parkinson's disease. Neurotherapeutics 8, 539-548.

Liu, G.H., Sancho-Martinez, I., and Izpisua Belmonte, J.C. (2012a). Cut and Paste: restoring cellular function by gene correction. Cell 
Res 22, 283-284.

Liu, G.H., Suzuki, K., Qu, J., Sancho-Martinez, I., Yi, F., Li, M., Kumar S., Nivet, E., Kim, J., Soligalla, R.D., et al. (2011). Targeted gene correction of laminopathy-associated LMNA mutations in patient-specific iPSCs. Cell Stem Cell 8, 688-694.

Liu, X., Li, F., Stubblefield, E.A., Blanchard, B., Richards, T.L., Larson, G.A., He, Y., Huang, Q., Tan, A.C., Zhang, D., et al. (2012b). Direct reprogramming of human fibroblasts into dopaminergic neuron-like cells. Cell Res 22, 321-332.

Lujan, E., Chanda, S., Ahlenius, H., Sudhof, T.C., and Wernig, M. (2012). Direct conversion of mouse fibroblasts to self-renewing, tripotent neural precursor cells. Proc National Acad Sci USA. doi: 10.1073/pnas.1121003109.

Marchetto, M.C., Carromeu, C., Acab, A., Yu, D., Yeo, G.W., Mu, Y., Chen, G., Gage, F.H., and Muotri, A.R. (2010). A model for neural development and treatment of Rett syndrome using human induced pluripotent stem cells. Cell 143, 527-539.

Nguyen, H.N., Byers, B., Cord, B., Shcheglovitov, A., Byrne, J., Gujar, P., Kee, K., Sch,le, B., Dolmetsch, R.E., Langston, W., et al. (2011). LRRK2 mutant iPSC-derived DA neurons demonstrate increased susceptibility to oxidative stress. Cell Stem Cell 8, $267-280$.

Nori, S., Okada, Y., Yasuda, A., Tsuji, O., Takahashi, Y., Kobayashi, Y., Fujiyoshi, K., Koike, M., Uchiyama, Y., Ikeda, E., et al. (2011). Grafted human-induced pluripotent stem-cell-derived neurospheres promote motor functional recovery after spinal cord injury in mice. Proc Natl Acad Sci USA 108, 16825-16830.

Pan, H., Zhang, W., and Liu, G.H. (2011). Find and replace: editing human genome in pluripotent stem cells. Protein Cell 2, 950-956.

Park, I.H., Arora, N., Huo, H., Maherali, N., Ahfeldt, T., Shimamura, A., Lensch, M.W., Cowan, C., Hochedlinger, K., and Daley, G.Q. (2008). Disease-specific induced pluripotent stem cells. Cell 134, 877-886.

Pasca, S.P., Portmann, T., Voineagu, I., Yazawa, M., Shcheglovitov, A., Pasca, A.M., Cord, B., Palmer, T.D., Chikahisa, S., Nishino, S., et al. (2011). Using iPSC-derived neurons to uncover cellular phenotypes associated with Timothy syndrome. Nat Med 17, 1657-1662.

Pawitan, J.A. (2011). Prospect of cell therapy for Parkinson's disease. Anat Cell Biol 44, 256-264.

Pfisterer, U., Kirkeby, A., Torper, O., Wood, J., Nelander, J., Dufour, A., Bjorklund, A., Lindvall, O., Jakobsson, J., and Parmar, M. (2011). Direct conversion of human fibroblasts to dopaminergic neurons. Proc Natl Acad Sci USA 108, 10343-10348.

Qiang, L., Fujita, R., Yamashita, T., Angulo, S., Rhinn, H., Rhee, D., Doege, C., Chau, L., Aubry, L., Vanti, W.B., et al. (2011). Directed conversion of Alzheimer's disease patient skin fibroblasts into functional neurons. Cell 146, 359-371.

Rhee, Y.-H., Ko, J.-Y., Chang, M.-Y., Yi, S.-H., Kim, D., Kim, C.-H., Shim, J.-W., Jo, A.Y., Kim, B.-W., Lee, H., et al. (2011). Protein-based human iPS cells efficiently generate functional dopamine neurons and can treat a rat model of Parkinson disease. J Clin Invest 121, 2326-2335.

Ross, C.A., and Poirier, M.A. (2004). Protein aggregation and neu- rodegenerative disease. Nat Med 10, S10-S17.

Roy, N.S., Cleren, C., Singh, S.K., Yang, L., Beal, M.F., and Goldman, S.A. (2006). Functional engraftment of human ES cell-derived dopaminergic neurons enriched by coculture with telomerase-immortalized midbrain astrocytes. Nat Med 12, 1259-1268.

Sanchez-Pernaute, R., Lee, H., Patterson, M., Reske-Nielsen, C., Yoshizaki, T., Sonntag, K.C., Studer, L., and Isacson, O. (2008). Parthenogenetic dopamine neurons from primate embryonic stem cells restore function in experimental Parkinson's disease. Brain: a journal of neurology 131, 2127-2139.

Schwartz, S.D., Hubschman, J.P., Heilwell, G., Franco-Cardenas, V., Pan, C.K., Ostrick, R.M., Mickunas, E., Gay, R., Klimanskaya, I., and Lanza, R. (2012). Embryonic stem cell trials for macular degeneration: a preliminary report. Lancet. Lancet. 2012 Jan 24 [Epub ahead of print].

Seifinejad, A., Tabebordbar, M., Baharvand, H., Boyer, L.A., and Salekdeh, G.H. (2010). Progress and promise towards safe induced pluripotent stem cells for therapy. Stem Cell Rev 6, 297-306.

Soldner, F., Hockemeyer, D., Beard, C., Gao, Q., Bell, G.W., Cook, E.G., Hargus, G., Blak, A., Cooper, O., Mitalipova, M., et al. (2009). Parkinson's disease patient-derived induced pluripotent stem cells free of viral reprogramming factors. Cell 136, 964-977.

Son, E.Y., Ichida, J.K., Wainger, B.J., Toma, J.S., Rafuse, V.F., Woolf, C.J., and Eggan, K. (2011). Conversion of mouse and human fibroblasts into functional spinal motor neurons. Cell Stem Cell 9, 205-218.

Swistowski, A., Peng, J., Liu, Q., Mali, P., Rao, M.S., Cheng, L., and Zeng, X. (2010). Efficient generation of functional dopaminergic neurons from human induced pluripotent stem cells under defined conditions. Stem Cells 28, 1893-1904.

Tsuji, O., Miura, K., Okada, Y., Fujiyoshi, K., Mukaino, M., Nagoshi, N., Kitamura, K., Kumagai, G., Nishino, M., Tomisato, S., et al. (2010). Therapeutic potential of appropriately evaluated safe-induced pluripotent stem cells for spinal cord injury. Proc Natl Acad Sci USA 107, 12704-12709.

Varela, C., Denis, J.A., Polentes, J., Feyeux, M., Aubert, S., Champon, B., Pietu, G., Peschanski, M., and Lefort, N. (2012). Recurrent genomic instability of chromosome $1 q$ in neural derivatives of human embryonic stem cells. J Clin Invest 122, 569-574.

Vierbuchen, T., Ostermeier, A., Pang, Z.P., Kokubu, Y., Sudhof, T.C., and Wernig, M. (2010). Direct conversion of fibroblasts to functional neurons by defined factors. Nature 463, 1035-1041.

Wernig, M., Benninger, F., Schmandt, T., Rade, M., Tucker, K.L., Bussow, H., Beck, H., and Brustle, O. (2004). Functional integration of embryonic stem cell-derived neurons in vivo. J Neurosci: the official journal of the Society for Neuroscience 24, 5258-5268.

Wernig, M., Zhao, J.-P., Pruszak, J., Hedlund, E., Fu, D., Soldner, F., Broccoli, V., Constantine-Paton, M., Isacson, O., and Jaenisch, R. (2008). Neurons derived from reprogrammed fibroblasts functionally integrate into the fetal brain and improve symptoms of rats with Parkinson's disease. Proc Natl Acad Sci USA 105, 58565861.

Yagi, T., Ito, D., Okada, Y., Akamatsu, W., Nihei, Y., Yoshizaki, T., 
Yamanaka, S., Okano, H., and Suzuki, N. (2011). Modeling familial Alzheimer's disease with induced pluripotent stem cells. Human Mol Genet 20, 4530-45839.

Yamashita, T., Kawai, H., Tian, F., Ohta, Y., and Abe, K. (2011). Tumorigenic development of induced pluripotent stem cells in ischemic mouse brain. Cell Transplant 20, 883-891.
Yang, D., Zhang, Z.J., Oldenburg, M., Ayala, M., and Zhang, S.C. (2008). Human embryonic stem cell-derived dopaminergic neurons reverse functional deficit in parkinsonian rats. Stem Cells 26, 55-63.

Zhang, W., Ding, Z., and Liu, G.H. (2012). Evolution of iPSC disease models. Protein Cell. Protein Cell 3, 1-4. 